\title{
Avian claw morphometry and growth determine the temporal pattern of archived stable isotopes
}

\author{
Steffen Hahn, Dimitar Dimitrov, Saskia Rehse, Elizabeth Yohannes and Lukas Jenni \\ S. Hahn (steffen.hahn@vogelwarte.ch) and L. Jenni, Dept of Bird Migration, Swiss Ornithological Inst., Seerose 1, CH-6204 Sempach, \\ Switzerland. - D. Dimitrov, Inst. of Biodiversity and Ecosystem Research, Bulgarian Academy of Sciences, Sofia, Bulgaria. - S. Rehse and \\ E. Yohannes, Limnological Inst., Univ. of Konstanz, Konstanz, Germany.
}

\begin{abstract}
Detailed knowledge about claw formation and growth rate is a prerequisite for the interpretation of avian claw stable isotopes, as is commonly done with feather stable isotopes to e.g. infer habitat use, dietary specialisations, and spatial occurrence. In this study, we provide basic information about claw formation and empirical evidence about the time scale of archiving isotopic information to develop a reliable assessment of archived isotopic pattern in claws of passerines. Avian claws grow conically from the tip of the bone of the phalanx. The length of the tip of an avian claw, suitable for stable isotope analysis, is about $42 \pm 6.8 \%$ (SD) of total linear claw length and can also be estimated from the body mass of a given species. Claw growth rate in adult songbirds typically ranged between 0.03 and $0.05 \mathrm{~mm} \mathrm{~d}^{-1}$, but differed between front and back toes, and varied seasonally. From the claw growth rate, the archiving period of a given claw length can be estimated. In long-distance migrant species, $\delta^{13} \mathrm{C}$ of claws matched $\delta^{13} \mathrm{C}$ of feathers grown during the same period (wintering or breeding period). In Palaearctic-African migrants sampled in the breeding season, $\delta^{13} \mathrm{C}$ of the distal half of the claw tip reflected the African wintering site, while the proximal half reflected a blend of African and European $\delta^{13} \mathrm{C}$ signatures, as expected. Hence there is empirical evidence that entire claw tips mirror the isotopic environments over longer periods (up to months), and over weeks when parts can be analysed. However any part of a claw contains a blend of material formed at different times due to the claw's conical (i.e. longitudinal and lateral) growth. Avian claws provide a complementary isotope archive for investigations, but its applicability may vary according to the ecology of the study species.
\end{abstract}

An animal's tissue stable isotope compositions reflect the corresponding elemental isotopic composition of its food. Depending on the element and knowledge of the time of the uptake, inference can be made about habitat use, dietary specialisations, and spatial occurrence (Hobson 2011). Ecologists take advantage of specific and predictable patterns in the natural abundance of stable isotopes from local to continental scales (Gannes et al. 1998). The information provided by stable isotopes varies according to tissue specific turn-over rates and the fate of the tissue, i.e. remaining metabolically active or inert (Hobson and Clark 1992, Bearhop et al. 2002, Hahn et al. 2012). In birds, isotope compositions of feathers are widely used to infer information during the restricted time of moult (Inger and Bearhop 2008) or, more specifically, about the time of renewal of the specific feather if different feathers are renewed at different times (Hoye et al. 2012). Other keratinous structures like beak and claw grow continuously (Lucas and Stettenheim 1972, Ethier et al. 2010) and thus steadily archive the isotopic composition of the diet (Bearhop et al. 2003) while shedding the oldest parts in the process. Thus, the chemical composition of claws can provide complementary information to that of feathers. The stable isotopes in claws have been less frequently used compared to feathers, although claws are metabolically inert after formation and might have a defined time frame of formation complementing other tissues. This may be related to our incomplete knowledge about the morphology of claw formation and growth rate and thus the time of stable isotope archiving (Bearhop et al. 2003, Boyle et al. 2011, Barquete et al. 2013) which is an essential prerequisite for proper interpretation of avian claw stable isotopes.

The aim of this study is to provide fundamental information on claw morphometry and growth allowing for a robust assessment of archived isotopic signatures in claws of passerines. To this end we a) review the particular morphological formation of avian claws, b) provide estimates of the time span of formation of avian claws based on the length of claw tip (which is often used when clipping claws on live birds) and c) provide empirical evidence whether claw stable isotopes reflect the corresponding dietary isotopic changes at seasonal and shorter time scales. 


\section{Material and methods}

\section{Claw morphometry and claw growth}

We measured claw length of the back toe and the central front toe in 117 adult individuals of 29 passerine species. The data set comprised bush/tree dwellers, reed climbers and ground dwelling species with an average body mass between 5.6 and $103.4 \mathrm{~g}$ (see Supplementary material Appendix 1, Table A1 for a list of species and sample size). Birds were killed by cats or cars and casualties at bird ringing stations (mainly from Col de Bretolet, Switzerland, Ventotene, Italy, and Rybachy, Russia).

All claws were photographed and a longitudinal section was prepared. Photographs were used to measure a) the linear length of the claw, i.e. the standard measure in the field, from the point where the dorsal keratin sheet emerges from the claw bed to the claw tip (Svensson 1992, Fig. 1, distance $\mathrm{AC}$ ) and b) the corresponding curved claw length along the surface of the dorsal plate. With a stereo microscope $( \pm 0.02 \mathrm{~mm})$ we measured the length of the firm keratinous part of the claw tip from the tip of the inner conical bone of the toe to the tip of the claw (Fig. 1, distance BC) from the longitudinal sections. Additionally, we derived the average body mass of species from Cramp (2004) for body mass - claw length comparison.

We determined daily growth rates of back toe claws and the central front toe claws in ten spanish sparrows Passer hispaniolensis held in aviaries during the nonbreeding season 2010/2011 at the Kalimok field station (Bulgaria). Birds were captured in October before autumn migration. We scored the keratin sheath of the claws on the dorsal side with a scalpel in mid-November. Claw growth was measured using callipers $( \pm 0.05 \mathrm{~mm})$ in $40 \mathrm{~d}$ intervals for $160 \mathrm{~d}$. The aviaries contained suitable vegetation and their ground was covered by sand mimicking natural conditions for claw abrasion as in the wild; food was supplied ad libitum.

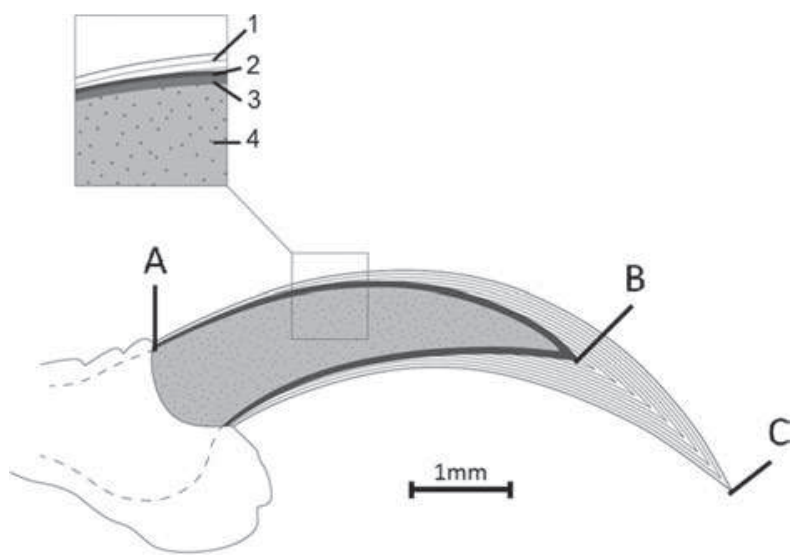

Figure 1. Schematic longitudinal section of a passerine back toe claw (based on a coal tit Periparus ater specimen). The corneous keratin sheets (1) rest on the germinate layer (2) and the dermis (3), both covering the entire conical bone (4) (histology adapted from Lucas and Stettenheim 1972). The claw measurements of this study include the linear claw length (distance AC), the curved claw length (distance $\mathrm{AC}$, along the surface of the dorsal plate), and the length of the keratinous claw tip (distance BC) which is used for analysing stable isotope composition.

\section{Claw and feather isotope profiles - seasonal patterns}

We determined the seasonal pattern of claw and feather stable isotope composition from long-distance migrants with different moult strategies in two migration seasons.

During autumn migration we collected the claw tips of back toes (approx. $2 \mathrm{~mm}$ length) and of one primary feather (about $7 \mathrm{~mm}$ ) from six common redstarts Phoenicurus phoenicurus and seven tree pipits Anthus trivialis at the Alpine pass Col de Bretolet ( $46^{\circ} 09^{\prime} \mathrm{N}, 06^{\circ} 46^{\prime} \mathrm{E}$, Switzerland, 14-16 September 2011).

During spring migration, we collected similar samples from redstarts, tree pipits, as well as from garden warblers Sylvia borin and spotted flycatchers Muscicapa striata (6 individuals per species) at the island of Asinara $\left(41^{\circ} 05^{\prime} \mathrm{N}\right.$, $08^{\circ} 19^{\prime} \mathrm{E}$, Italy, 21 April-2 May 2012), one of the first staging sites for passerines after crossing the Mediterranean Sea. The breeding or wintering origin of the birds on migration was not known.

Redstarts and tree pipits undergo a complete postbreeding moult in Europe (European moult, EM); garden warblers and spotted flycatchers generally moult during the non-breeding season in Africa (African moult, AM) (Cramp 2004).

In order to differentiate tissue from feathers or claws grown in the African wintering area or in Europe, we used the stable carbon isotope ratio $\left(\delta^{13} \mathrm{C}\right) \cdot \delta^{13} \mathrm{C}$ of plants using the $\mathrm{C}_{3}$ photosynthetic pathway $\left(\delta^{13} \mathrm{C}\right.$ of $\mathrm{C}_{3}$ plants $-26.7 \pm 2.3$ (SD) \%o) differs markedly from plants using the $\mathrm{C}_{4}$ pathway $(-12.5 \pm 1.1(\mathrm{SD}) \%$; Cerling et al. 1997). $\mathrm{C}_{4}$ plants, mainly monocotyledons are representative of dry open grassland habitats in Africa (Sage and Monson 1999) and $\mathrm{C}_{3}$ plants predominate in all natural habitats in Europe (West et al. 2010).

Because the $\delta^{13} \mathrm{C}$ differences pass through the food chain, we expected large differences in $\delta^{13} \mathrm{C}$ between tissues grown in Europe and those grown in xeric habitats in Africa. If claws and feathers are grown during the same period and at the same location, their $\delta^{13} \mathrm{C}$ should be similar. Hence, we expected similar $\delta^{13} \mathrm{C}$ in feathers $\left(\delta^{13} \mathrm{C}_{\text {feather }}\right)$ and claws $\left(\delta^{13} \mathrm{C}_{\text {claws }}\right)$ from EM species in autumn and from AM species in spring.

\section{Within-claw isotope profiles}

Avian claws grow continuously (Lucas and Stettenheim 1972, Ethier et al. 2010) and its keratin composition should mirror changes in isotope composition of the diet. Thus, a change in $\delta^{13} \mathrm{C}$ from African $\mathrm{C}_{4}$-dominated xeric habitats to $\mathrm{C}_{3}$-dominated European habitats in birds moving from Africa to Europe should be traceable as a gradient from the oldest to the most recently formed keratin in claws. Accordingly, the distal portion of the claw tip (supposed to have grown entirely in Africa during winter) is expected to have a higher $\delta^{13} \mathrm{C}$ value than proximal parts of the claw tip (assumed to have grown on migration). Both parts of the claw are expected to differ in $\delta^{13} \mathrm{C}$ from feathers grown at European breeding sites.

We analysed samples of back toe claw tips and of primary feather tips from nine common nightingales Luscinia megarhynchos captured at their breeding sites in 
Italy and Bulgaria in May 2009 and 2010 (average capture date: 19 May). Nightingales show large variation in $\delta^{13} C_{\text {claw }}$ indicating that individuals winter in xeric and in moist African habitats (Hahn et al. 2013). From a large sample collected for another study, we selected five individuals (two from Italy, three from Bulgaria), which are likely to have grown their claw in xeric habitat in Africa $\left(\delta^{13} \mathrm{C}\right.$ of entire claw $>-18 \%$ ) and four individuals (from Bulgaria) which wintered in moist habitat $\left(\delta^{13} C_{\text {claw }}<-20 \%\right.$ ) (for details see Hahn et al. 2013). Each claw sample (approx. $2 \mathrm{~mm}$ long) was cut into half: the distal tip and the proximal part. Nightingales departed from their wintering sites at the end of March and arrived at the breeding sites in mid-April (Hahn et al. unpubl.), indicating that these claw samples had been collected about 1.5-2 months after departure from the wintering sites and about $2-3$ weeks after arrival at the breeding site.

\section{Determination of $\delta^{13} \mathrm{C}$}

All feather and claw samples were cleaned with hexane to remove contaminations, and were air-dried under a fume hood. Sub-samples of about 100-200 $\mu \mathrm{g}$ were analysed for $\delta^{13} \mathrm{C}$ in a vario Micro cube elemental analyser (Elementar Analysensysteme, Germany). The resulting gases were led via gas chromatography into the inlet of a Micromass (Manchester, UK) Isoprime Isotope Ratio Mass Spectrometer (IRMS). Measurements are reported in $\delta$-notation in parts per thousand deviations (\%o) relative to international standard for carbon (Pee Dee Belemnite, PDB) according to $\delta=1000 \times\left(\mathrm{R}_{\text {sample }} / \mathrm{R}_{\text {standard }}\right)-1 \%$. Internal laboratory standards indicated measurement errors (SD) of $\pm 0.05 \%$ o for $\delta^{13} \mathrm{C}$.

\section{Results}

\section{Claw formation}

The keratinous and calcified part of the bird's toe ('claw') is a derivative of the integument (Stettenheim 2000). The claw is formed by a dorsal (unguis) and a ventral keratin plate (sub-unguis) covering the terminal phalanx (Lucas and Stettenheim 1972, Alibardi 2009). Both plates mesh in longitudinal direction forming a firm tip (Fig. 1). In a longitudinal section, the outermost corneous layers of the dorsal and ventral plates are followed by the germinate layer (the plates and the germinate layer are epidermal structures), and more to the interior by the dermis and finally the bone of the phalanx (Fig. 1 inset). These layers, including the germinate layer, cover the whole cone of the bone. Therefore, both keratin plates grow mainly in the longitudinal direction towards the tip, but also to some extent in the lateral direction (thickness) (Lucas and Stettenheim 1972, Alibardi 2009). Consequently, the claw tip is composed of a mixture of keratinous material of different age: the most recently formed keratin is found at the tip of the bone, i.e. at the base of the claw tip; older material is found predominantly at the distal part of the claw tip (see also Bearhop et al. 2003). Thus, avian claws do not grow in a simple linear fashion as hair or feathers, but more conically as horns.

\section{Claw morphometry and growth}

The mean linear length of claws of 29 European passerine species varied between 3.5 and $9.1 \mathrm{~mm}$ in front toes and between 4.2 and $15.9 \mathrm{~mm}$ in back toes (Supplementary material Appendix 1, Table A1). The individual difference between the linear and the curved measure of claw length was $1.08 \mathrm{~mm}$ (median; 25/75percentile: 0.90-1.22 mm, $\mathrm{n}=112)$ in back toe claws and $0.65 \mathrm{~mm}(25 / 75$ percentile: $0.48-0.80 \mathrm{~mm}, \mathrm{n}=109)$ in central front toe claws. The difference was smallest in back toes of skylarks and meadow pipits with particularly straight claws (median: $0.3 \mathrm{~mm}$, $\mathrm{n}=4)$.

Mean claw tip length (Fig. 1) varied between 1.4 and 6.1 $\mathrm{mm}$ in back toes and between 1.3 and $3.6 \mathrm{~mm}$ in central front toes ( $n=29$ species). Claw tip length was positively related to species average body mass for back toes and front toes (Table 1, Fig. 2a, Supplementary material Appendix 1, Fig. A1a). The fit of the regression for back toe claws to logarithmic body mass increased considerably when species with straight long claws, i.e. the pipits and larks, were excluded (Table 1).

The length of the claw tip is linearly related to total claw length (reduced major axis regression, Table 1, Fig. 2b, Supplementary material Appendix 1, Fig. A1b). The slope of 0.54 for central front toe and of 0.57 for back toe claws (Table 1 ) was statistically similar ( $\mathrm{t}$-test: $\mathrm{t}=0-55, \mathrm{p}=0.58$ ). This suggests that for all claws the claw tip is about $42 \pm 6.8 \%$ (SD) of total linear claw length.

The growth rate of claws of Spanish sparrows was lower for front toes $\left(0.034 \pm 001 \mathrm{~mm} \mathrm{~d}^{-1}(\mathrm{SD}), 25-75\right.$ percentile: $\left.0.026-0.040 \mathrm{~mm} \mathrm{~d}^{-1}\right)$ than for back toes $(0.040 \pm 001 \mathrm{~mm}$ $\mathrm{d}^{-1}(\mathrm{SD}), 25-75$ percentile: $0.034-0.048 \mathrm{~mm} \mathrm{~d}^{-1}$, paired $\mathrm{t}$-test $\mathrm{t}=2.92, \mathrm{p}=0.007)$. Growth rates varied within the

Table 1. Reduced major axis regression of claw tip length $(\mathrm{Y})$ versus logarithmic average body mass per species or total claw length. Regressions are of the form $\mathrm{Y}=\mathrm{a}+\mathrm{b} \times \mathrm{X}$. Parameter estimates are given as means $\pm \mathrm{SE}$.

\begin{tabular}{lcccc}
\hline Y - claw tip length & $\mathrm{b}$ & $\mathrm{A}$ & $\mathrm{R}^{2}$ & $\mathrm{n}$ \\
\hline$X-$ lg(average body mass) & & & \\
$\quad$ Front toe & $1.936 \pm 0.283$ & $-0.109 \pm 0.356$ & 0.42 & 29 \\
$\quad$ Back toe & $4.201 \pm 0.700$ & $-2.371 \pm 0.882$ & 0.25 & 29 \\
$\quad$ Back toe excl. larks and pipits & $2.509 \pm 0.401$ & $-0.493 \pm 0.500$ & 0.36 & 27 \\
$X$ - total claw length & & & & 106 \\
$\quad$ Front toe & $0.54 \pm 0.035$ & $-0.51 \pm 0.182$ & 0.57 & 110 \\
$\quad$ Back toe & $0.57 \pm 0.028$ & $-1.02 \pm 0.187$ & 0.74 & \\
\hline
\end{tabular}



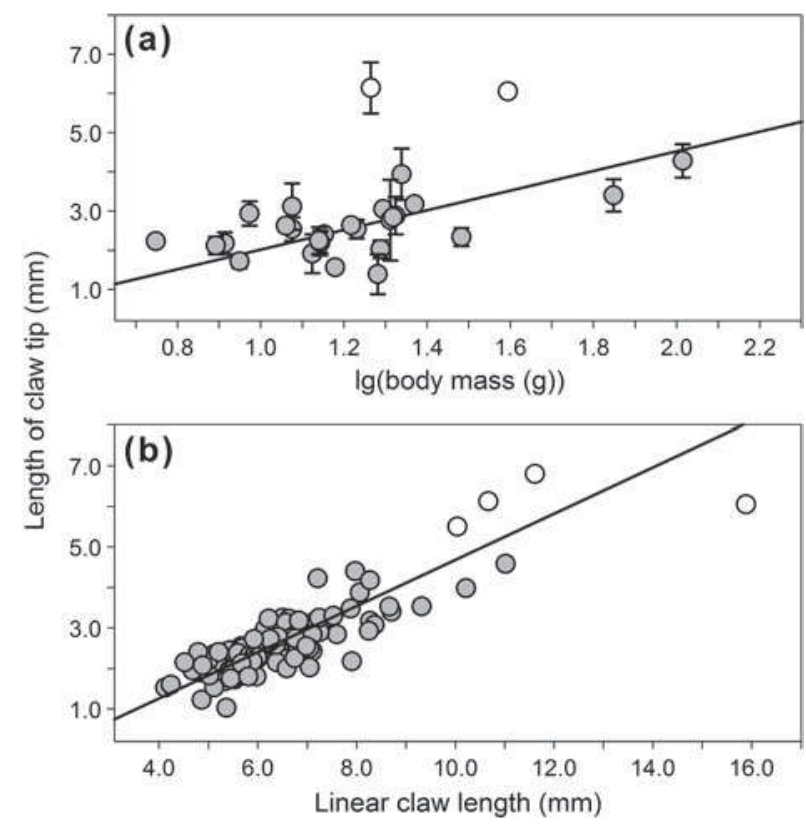

Figure 2. Relationship of claw tip length with (a) average body mass or (b) linear claw length in back toes of 27 passerine species (grey circles) and meadow pipit and skylarks (white circles). Claw tip length in (a) is given as means $\pm \mathrm{SD}$; lines give reduced major axis linear regressions (for statistics see Table 1).

winter season (RM ANOVA for front toe: $F_{3,31}=5.93$, $\mathrm{p}=0.005$, for back toe: $\mathrm{F}_{3,31}=9.32, \mathrm{p}=0.001$ ) with highest rates at the beginning of the experiment in late autumn (Fig. 3).

\section{Claw and feather isotope profiles - seasonal patterns}

$\delta^{13} \mathrm{C}$ of claws and feathers grown during the same period (EM species in autumn and AM species in spring) are highly correlated $(\mathrm{r}=0.92, \mathrm{p}=0.001, \mathrm{n}=25$, Supplementary material Appendix 1, Fig. A2), but differed on average by $0.62 \%$ o \pm 0.19 (SE) (repeated measures (RM) ANOVA,

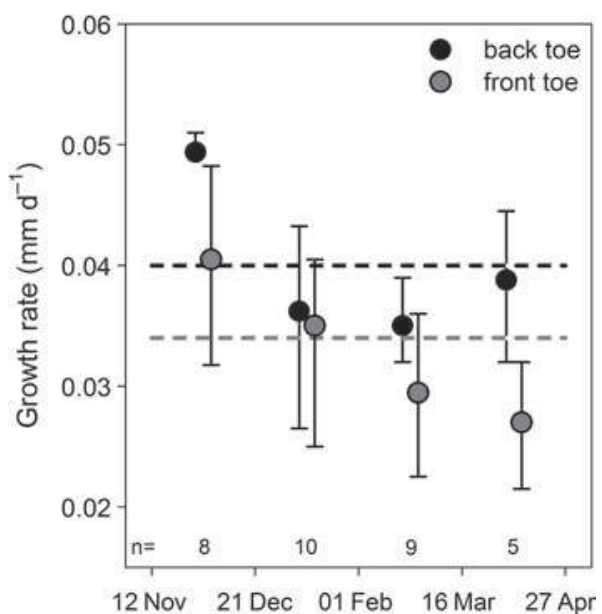

Figure 3. Temporal variation in mean growth rates $\left(\mathrm{mm} \mathrm{d}^{-1}\right)$ of back toe (black) and central front toe claws (grey) of captive Spanish sparrows. Error bars are 25/75 percentiles, the dotted lines are the overall means for back and front toe. factor tissue: $F_{1,49}=1636, p=0.001$; interaction tissue $X$ species: $\mathrm{F}_{3,49}=0.70, \mathrm{p}=0.56$; Fig. 4). Consequently, the difference in apparent diet-tissue discrimination factors between feathers and claws was similar in the four tested species.

As expected, the difference between $\delta^{13} \mathrm{C}$ of claws and feathers in the two EM species in spring, which had been grown during different periods, was large and averaged $3.1 \%$ in redstarts and $9.16 \%$ in pipits (Fig. 4, RM ANOVA factor tissue: $\mathrm{F}_{1,23}=28.17, \mathrm{p}=0.001$; factor species: $\mathrm{F}_{1,23}=0.09, \mathrm{p}=0.78$, interaction tissue $\times$ species: $\left.\mathrm{F}_{1,23}=6.67, \mathrm{p}=0.03\right)$.

We found only a slight, non-significant difference in $\delta^{13} \mathrm{C}_{\text {feather }}$ between spring and autumn in the two EM species (redstart $\mathrm{t}_{11}=2.07, \mathrm{p}=0.07$; pipit $\mathrm{t}_{10}=1.11$, $\mathrm{p}=0.29$ ) indicating that the birds caught in autumn might have moulted in different habitats than the birds caught in spring.

\section{Within-claw isotope profiles}

In the nightingales sampled in the breeding season, $\delta^{13} \mathrm{C}$ values differed between tissue (distal and proximal part of claw tip and feather; RM ANOVA, $\mathrm{F}_{2,26}=416.6, \mathrm{p}=0.001$, Fig. 5) and between birds from xeric and moist African habitats $\left(\mathrm{F}_{1,26}=212.1, \mathrm{p}=0.001\right.$, interaction tissue $\times$ habitat: $\mathrm{p}=0.001)$. Pairwise comparisons revealed statistical differences between all tissues in birds of both habitats (Holm-Sidak posthoc tests: $\mathrm{p}<0.05$ ), except between the distal and the proximal parts of the claw tip in moist habitat birds (Holm-Sidak $\mathrm{t}=1.69, \mathrm{p}=0.11$ ). Moreover, $\delta^{13} C_{\text {feather }}$ was similar in all birds (grown in Europe: $\mathrm{t}=1.15, \mathrm{p}=0.26$ ).

\section{Discussion}

This study gives empirical evidences to support the use of avian claws as reliable archives for tracking changes in isotope composition in diet. All morphological measures, growth

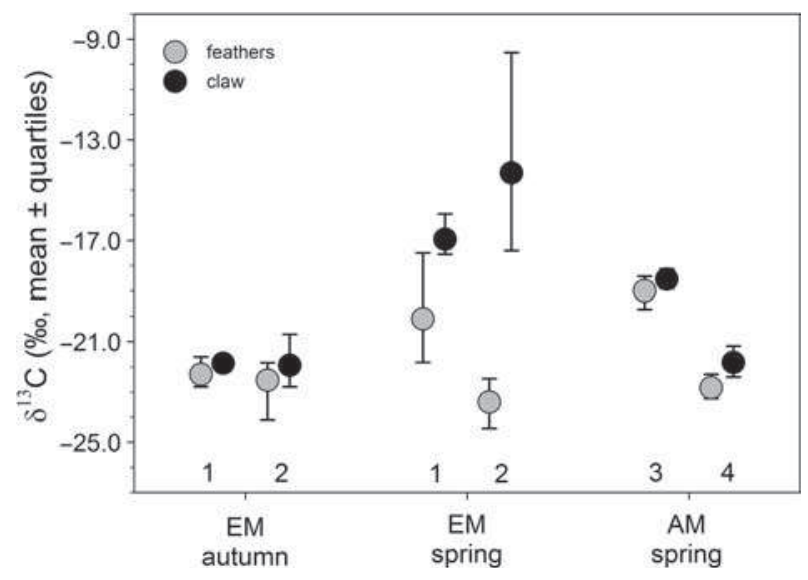

Figure 4. Stable carbon isotope ratios $\left(\delta^{13} \mathrm{C}\right)$ of claw tips (black dots) and primary feathers (grey dots) of passerines undergoing a complete moult in Europe (EM) or in Africa (AM). Birds were captured after leaving their breeding areas (EM autumn) and after leaving their wintering areas (EM/AM spring). $1=$ common redstart, $2=$ tree pipit, $3=$ spotted flycatcher, $4=$ garden warbler. 


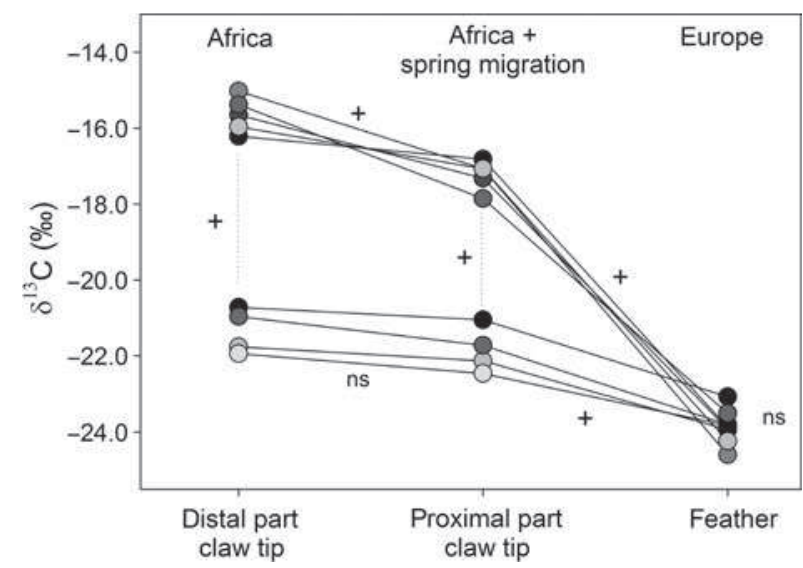

Figure 5. Stable carbon isotope ratios $\left(\delta^{13} \mathrm{C}\right)$ archived in the distal and proximal half of the claw tip and in feathers of nightingales captured at their breeding sites in spring. Four and 5 nightingales of two groups with greatly differing $\delta^{13} \mathrm{C}$ values in entire claw tips were selected, representing individuals having wintered in dry and moist areas, respectively. The distal part of the claw tip has been grown at the African winter site, the proximal part during the late wintering and the spring migration period. The feathers were formed in the preceding summer in Europe. Crosses indicate statistically significant differences and ns no differences.

rates, and archiving periods reflected by claw tips estimated using $\delta^{13} \mathrm{C}$ will also apply to different stable isotopes (like $\delta^{15} \mathrm{~N}$ and $\left.\delta^{2} \mathrm{H}\right)$. We provide estimates of the length of the keratinous claw tip depending on total claw length and on body size for passerines. Claw tip growth periods (in relation to sampling date) can be determined using estimates of the entire (total) claw growth period: the length of the claw tip appeared to be roughly $42 \%$ of total linear claw length or about $0.033 \times$ body mass +1.88 (for back toe, excluding larks and pipits, see Table 1) and grows with an average rate of $0.04 \mathrm{~mm} \mathrm{~d}^{-1}$. Hence for a $20 \mathrm{~g}$ passerine, the back toe claw tip of about $2.54 \mathrm{~mm}$ would have grown during 2 months (63 d). Knowledge of claw composition and the formation period are fundamental for stable isotope data interpretation, but are difficult to achieve.

For instance, Fraser et al. (2008), based on daily rate of $\delta^{2} \mathrm{H}$ exchange and total claw length, expected a 16-17 weeks archiving period in claw tips in golden winged warbler Vermivora chrysoptera and cerulean warbler Setophaga cerulea. However, they found an archiving period in tips of 1-2 mm length of only 3-7 weeks in distal and proximal parts of front toe claws. When applying our average claw growth rate of $0.034 \mathrm{~mm} \mathrm{~d}^{-1}$ (front toe, Fig. 3) to their claw tip length we can confirm a formation period of the tip of 4.2 and 8.4 weeks prior sample collection. Mazerolle and Hobson (2005) found unexpected large differences in isotope composition between distal and proximal halves of claw tips in migratory white-throated sparrows Zonotrichia albicollis (body mass $21.1 \mathrm{~g}$, Dunning 1993) with an isotope composition of the proximal half being similar to isotope patterns at the collection site. They argued that claw growth rate was higher than expected or claw composition affected isotope composition. When using the relationship of body mass-claw tip length (front toe, Table 1) we would estimate a claw tip length of $2.45 \mathrm{~mm}$ for the study species. Hence the proximal half of the tip (total claw samples averaged 1-2.5 mm long) used by Mazerolle and Hobson (2005) should be very close or even in touch with the germinate layer which must result in a stable isotope signature biased towards the point of sampling. This rejects the idea of extraordinary fast growing claws in this species.

Our estimates of claw tip length and growth rate are robust for applying to various passerine species. However, additional studies that refine the current findings are required. For example, claw tip length may deviate from that estimated from a general regression with total claw length, or with body mass, depending on ecological guilds (e.g. aerial foragers) or species (for non-passerines Glen and Bennett 2007, Csermely et al. 2012). Thus far, there are only two publications on claw growth rate of passerine species associated with woodland or semi-open habitat (Bearhop et al. 2003, Boyle et al. 2011) and much less is known in other avian orders (Supplementary material Appendix 1, Table A2). It is important to investigate how claw growth rate (or abrasion) varies with habitat (responding to different abrasion rates) and between seasons (some evidence is given in Fig. 3). It is also necessary to examine whether longer claws, i.e. back toe claws, on the same individual grow at the same rate (and hence providing information over a longer time span) or at a faster rate than shorter claws.

Both our tests on the use of claw $\delta^{13} \mathrm{C}$ provided the expected results. First, feathers and claws presumably grown at the same place and time showed similar $\delta^{13} \mathrm{C}$ values. Nevertheless, we report a minor difference in that claws had $0.62 \%$ lower $\delta^{13} \mathrm{C}$ values than feathers, while Bearhop et al. (2003) reported exactly the opposite (Supplementary material Appendix 1, Fig. A2). Second, a dietary shift in $\delta^{13} \mathrm{C}$ is reflected in a gradual change of $\delta^{13} \mathrm{C}$ within a single claw, such that distal and proximal parts of the claw tip represent older and younger archives, respectively. If a change in dietary stable isotopes occurs during the period of claw tip formation and the claw tip is analysed as a whole (proximal and distal parts taken together), the resulting values are a blend of stable isotopes before and after the dietary shift. Also the proximal or the distal part of the claw tip, taken separately, may contain nutrients obtained at different time periods. This is because claws grow conically and not linearly and the outer layers are always older than the inner layers for a given cross-section (Fig. 1).

In summary, the keratinous tip of claws of passerines integrates the isotope signatures of the diet over a few months. Yet, analysis of distinct parts of claw portions (e.g. the proximal part) provides an integrated isotopic signature over few weeks. The archived time is directly related to the sampling date which is in contrast to full-grown feathers for which the time of growth is determined by the moult cycle of the species.

Acknowledgement - We thank F. Korner-Nievergelt, S. Althaus and L. Serra for collecting samples, N. Znakovaite, L. Cadotsch and M. Bastardot for lab assistance, C. Erdös for drawing Fig. 1, and S. Bearhop for original data. The study was supported by a research grant of the German Ornithological Society to SH. 


\section{References}

Alibardi, L. 2009. Claw development and cornification in the passeraceous bird zebrafinch (Taeniatopygia guttata castanotis). - Anat. Sci. Int. 84: 189-199.

Barquete, V., Strauss, V. and Ryan, P. G. 2013. Stable isotope turnover in blood and claws: a case study in captive African penguins. - J. Exp. Mar. Biol. Ecol. 448: 121-127.

Bearhop, S., Waldron, S., Votier, S. C. and Furness, R. W. 2002. Factors that influence assimilation rates and fractionation of nitrogen and carbon stable isotopes in avian blood and feathers. - Physiol. Biochem. Zool. 75: 451-458.

Bearhop, S., Furness, R. W., Hilton, G. M., Votier, S. C. and Waldron, S. 2003. A forensic approach to understanding diet and habitat use from stable isotope analysis of (avian) claw material. - Funct. Ecol. 17: 270-275.

Boyle, W. A., Guglielmo, C. G., Hobson, K. A. and Norris, D. R. 2011. Lekking birds in a tropical forest forego sex for migration. - Biol. Lett. 7: 661-663.

Cerling, T. E., Harris, J. M., MacFadden, B. J., Leakey, M. G., Quade, J., Eisenmann, V. and Ehleringer, J. R. 1997. Global vegetation change through the Miocene/Pliocene boundary. - Nature 389: 153-158.

Cramp, S. 2004. Birds of the Western Palearctic interactive. - Oxford Univ. Press.

Csermely, D., Rossi, O. and Nasi, F. 2012. Comparison of claw geometrical characteristics among birds of prey and non-raptorial birds. - Ital. J. Zool. 79: 410-433.

Dunning, J. B. 1993. CRC handbook of avian body masses. - CRC Press.

Ethier, D. M., Kyle, C. J., Kyser, T. K. and Nocera, J. J. 2010. Variability in the growth patterns of the cornified claw sheath among vertebrates: implications for using biogeochemistry to study animal movement. - Can. J. Zool. 88: 1043-1051.

Fraser, K. C., Kyser, T. K., Robertson, R. J. and Ratcliffe, L. M. 2008. Seasonal patterns in hydrogen isotopes of claws from breeding wood-warblers (Parulidae): utility for estimating migratory origins. - Avian Conserv. Ecol. 3: 2.

Gannes, L. Z., del Rio, C. M. and Koch, P. 1998. Natural abundance variations in stable isotopes and their potential uses in animal physiological ecology. - Comp. Biochem. Phys. A 119: 725-737.

Glen, C. L. and Bennett, M. B. 2007. Foraging modes of Mesozoic birds and non-avian theropods. - Curr. Biol. 17: R911-R912.

Hahn, S., Hoye, B. J., Korthals, H. and Klaassen, M. 2012. From food to offspring down: tissue-specific discrimination and turn-over of stable isotopes in herbivorous waterbirds and other avian foraging guilds. - PLoS One 7: e30242.

Hahn, S., Amrhein, V., Zehtindijev, P. and Liechti, F. 2013. Strong migratory connectivity and seasonally shifting isotopic niches in geographically separated populations of a long-distance migrating songbird. - Oecologia 173: 1217-1225.

Hobson, K. A. 2011. Isotopic ornithology: a perspective. - J. Ornithol. 152: 49-66.

Hobson, K. A. and Clark, R. G. 1992. Assessing avian diets using stable isotopes. 1. Turnover of C-13 in tissues. - Condor 94: 181-188.

Hoye, B. J., Hahn, S., Nolet, B. A. and Klaassen, M. 2012. Habitat use throughout migration: linking individual consistency, prior breeding success and future breeding potential. - J. Anim. Ecol. 81: 657-666.

Inger, R. and Bearhop, S. 2008. Applications of stable isotope analyses to avian ecology. - Ibis 150: 447-461.

Lucas, A. M. and Stettenheim, P. R. 1972. Avian anatomy integument part II. - United States Dept of Agriculture, Washington DC.

Mazerolle, D. F. and Hobson, K. A. 2005. Estimating origins of short-distance migrant songbirds in North America: contrasting inferences from hydrogen isotope measurements of feathers, claws, and blood. - Condor 107: 280-288.

Sage, R. F. and Monson, R. K. 1999. C4 plant biology. - Academic Press.

Stettenheim, P. R. 2000. The integumentary morphology of modern birds - an overview. - Am. Zool. 40: 461-477.

Svensson, L. 1992. Identification guide to European passerines. - British Trust for Ornithology, Stockholm.

West, J. B., Bowen, G. J., Dawson, T. E. and Tu, K. P. 2010. Isoscapes: understanding movement, pattern and process on earth through isotope mapping. - Springer. 